\title{
SUSTAINABILITY OF AN INTERIOR SPACE AS A CULTURAL HERITAGE
}

\author{
NUR AYALP \& A. MÜGE BOZDAYI \\ Tobb University of Economics and Technology, University in Ankara, Turkey.
}

\begin{abstract}
This study aims to develop a design model for sustainability of cultural setting, including its tangible and intangible components. The study focuses on the interior environment of traditional Turkish coffeehouse interiors as a case. This study introduces the Turkish coffeehouse interior space as cultural heritage. It describes both the historic social importance of the coffeehouse as well as the physical characteristics of a typical coffeehouse and proposes to engage people in a design process to recreate the Turkish coffeehouse's interior space. From an interior architectural perspective, the study sets typical features of the coffeehouse and aims to discuss the dimensions to sustain this cultural setting in today's living conditions.
\end{abstract}

Keywords: Cultural heritage, place, place identity, traditional Turkish coffeehouses.

\section{INTRODUCTION}

Defining a communal value as a cultural heritage consists of complex and a long-term formation. Defining an interior space as a cultural heritage; space consists of both aesthetic cultural values and the socio-cultural values. By reason of both the visual and behavioral dimensions of human behaviors are affective factors in the creation of this cultural value, this process become more complex. In fact, the interior space is the core environment that reflects the living habit of a society. In other words, it is the main medium containing the identity of a specific culture. In this way, sustaining an interior environment became an affective factor in sustaining both intangible and tangible parts of cultural heritage. This study focuses on different dimensions of interior space from the point of sustaining a cultural heritage. In addition, traditional Turkish coffeehouse's interior space is set as an example.

The Turkish coffeehouse is a place that represents the Turkish socio-cultural identity and was the first widely used public space of their culture. Coffeehouses have been present in Turkey for approximately 500 years, during which time drinking coffee became a way of socializing in Turkish culture. Historically, there were different locations within the Ottoman palace for serving and drinking coffee. Also special rituals were developed relating to drinking coffee.

UNESCO defines intangible cultural heritage from many different aspects, 'as a process and practices rather than end products', which is defined as 'sources of identity, creativity, diversity and social cohesion' [1]. Within Turkish culture, drinking coffee is a form of social cohesion that has represented our identity for 500 years. Even today, drinking Turkish coffee is a ritual that presents ties of friendship. In addition, making and serving the coffee forms part of the Turkish marriage ritual. While a bridegroom and his family seek permission from a woman's parents for her hand in marriage, the future bride prepares and serves them Turkish coffee. This ritual represents the skills of bride. Not just with its material value, but by setting and defining form of socialization, it also represents intangible cultural heritage of Turkish culture. In other words, through its social value, the coffeehouse also gains intangible value. Today, both intangible and tangible cultural elements have lost their value and meaning. The Burra Charter proposes to preserve the cultural significance of a site, defined in terms of its aesthetic, historic, scientific significance of social value [2]. 
Observed from this perspective, coffee, which has been in continuous use in Turkey from the 16th century until now, can be seen as an element of the country's cultural heritage. Typical Turkish coffee-making and presentation techniques, though they have evolved over time, have also come down to the present day without interruption. Coffeehouses have also emerged as 'interior spaces' over time and have continued as such until today. Therefore, these spaces have as much intrinsic value to Turkish culture as coffee itself. As Vecco indicates, 'while initially the historic and artistic values were the only parameters, other additional ones have now been added: the cultural value, its value of identity and the capacity of the object to interact with memory' [3].

\section{SPACE, PLACE AND IDENTITY}

This section explores certain concepts that will help explain the interaction that exists between these interior spaces, which have an important place in Turkish culture, and their users. There is a complex interaction between a person and a space. The person defines the space; the space defines the person. The person gives meaning to the space; the space gives meaning to the person. In other words, there is a complex and bilateral interaction between the person and the space in its cultural, psychological, economic, and physical dimensions. Coffeehouses, where intensive cultural influences may be observed, are spaces where this bilateral interaction can also be easily perceived.

According to Altman and Chemers, not just the living habit differs but also the perception of the environment is different in accordance to their culture [4]. Before introducing these examples, they state that different people living in different cultures have diverse spatial perceptions. The authors then establish that the culture, environment, and the individual constitute as a whole. They argue that the parts of this whole cannot be discussed independent of each other. They finally conclude that these interactions altogether constitute a social system.

When the interaction is approached from this perspective, the concept of place rather than space emerges, in which place includes space, time, and people. As Knez indicates, the place has 'physical, geographical, historical, religious, social and psychological, connotations and it is, in addition, located at the level of a spatial scale' [5]. According to Hay, when the human element is introduced, a space becomes more of a place than a space [6]. Law and Altman defined the place concept as the space which is given meaning through individual, group or cultural processes [7]. In other words, over time people can transform spaces into places. Thus, during the usage process, people create their own place identities, and this transform spaces into their own places. This process is defined in the relevant literature as 'place identity'. By this definition, identity, as it shifts over time, is described as a biological organization that develops through adjustment (settlement), assimilation, and assessment of the social world [8].The concept of place involves not just as a physical element but also as emotional factors. Hay describes the three factors that affect the formation of the place concept as follows:

1. Residence status in the place (superficial, partial, personal, a sense of place coming from the past)

2. Age status, as a developing cycle of life

3. Connections that develop in adulthood, generally marriage

No matter what space and time mean, place and occasion tell more [9]. People do not only create their spaces, the geography of their lives, but also the time-space (place) of their lives [10]. In short, the concept of place is fundamental to the individual and spatial interaction. Place should be perceived as a dimension of space which comes about through the individual's use of the space. 
As place identity, community identity is also a vital concept in understanding group behavior in coffeehouses. Tajfel set social identity as part of a self-concept that is gained through group membership [11]. According to this concept, the identity of the groups using a coffeehouse also affects the place identity of the space itself. Furthermore, studies of place identity formation set the cognition process as an element that affects the development of place identity. In this context, many studies claim that the community identity and global identity are affective factors in cognitive process [12]. In this way, the shaping of the interior of coffeehouses is affected by the community identity of the users.

It is certain that coffeehouses have an authentic place in Turkish culture. These spaces correspond to the concept of place rather than space. With their frequent use, people have helped these places to gain place identities in accordance with their needs. These groups, having formed the place identities, use these spaces almost like 'clubs', indicating that they have formed an attachment to particular places.

\section{HISTORICAL OVERVIEW TO TURKISH COFFEEHOUSES}

Coffee was introduced to Turkey by the Governor of Ethiopia, Özdemir Pasha, after the Ottoman conquest of Egypt and Hedjaz in the 16th century. According to a more precise source, Muslim merchants brought coffee into the Ottoman Empire in 1517 via Yemen, Jizyah, Cairo, and Alexandria [13]. By the 1600s, coffee was widely consumed in every corner of the empire. According to Evliya Celebi's Travel Book, in 1630, there were 55 coffeehouses in İstanbul alone.

The most striking evidence of the central importance of coffee culture to Turkish society is the 1971 census. The census revealed that there were no less than 1,259 coffeehouses in Beyoğlu (a fashionable district of İstanbul). For the majority of the public, these spaces have become the places where they spent most of their time outside of home and work.

Several different types of coffeehouses have emerged over time. Some are reading houses (kıraathane), janissary (yeniçeri) coffeehouses, and live entertainment (semai) coffeehouses. It is remarkable that janissaries founded their own typical coffeehouse. These coffeehouses were structured in much the same way as the military hierarchy. For instance, an ordinary soldier could not open a janissary coffeehouse; only a famous officer who was prominent among the group could open and run such a place. The 'live entertainment' coffeehouses were venues for the performing arts. Besides these, there were a number of other coffeehouses, each with a different generic name that catered to different clienteles from different professions.

As the above examples suggest, the coffeehouse space evolved from its basic and original function to become an environment where particular patrons could keep their own traditions and customs alive. These places, in earlier times, were the only environments for socialization outside of the mosque and workplace. They strongly reflected the cultural identities of the members of society they hosted. It might thus be suggested that coffeehouses not only reflected Turkish culture and traditions but also were significant spaces for the formation and practice of those cultures and traditions.

\subsection{Examination of interior space features}

The seating arrangements in coffeehouses are not so different from those of the sitting or guest rooms in an Ottoman mansion. Plan diagrams of coffeehouses reveal the same centric spatial understanding which is at the heart of the Ottoman Era's domestic sitting rooms.

Within the scope of this study, many coffeehouses in different provinces of Turkey were examined, and historical sources were used to examine defunct coffee shops. The findings indicate that the coffeehouse is a reflection of the architectural style of the Ottoman period. In interior space, 
Ottoman architecture manifests itself in intensive ornamentation. Especially within interior spaces of those identified as city coffeehouses, intensive Ottoman stylistic effects are observed, both in the seating arrangement and the accessories used in interior space.

Looking at Figs 1 and 2, it is seen in the planning that there is a central pool, faced by wooden bedstead seating units placed around the walls. This layout was convenient for coffeehouse customers to maintain a strong communication. The intensive cedar decoration used in the interior space and central pool reflect contemporary Ottoman aesthetic values. In addition, coffeehouses may include a top wooden bedstead divan. These top divans were located across the stove and may be accessed via a staircase and surrounded by fences. Top divans were an indicator of status differentiation in a coffeehouse. Generally, highly respected people were hosted in top divans. The difference in elevation was used as a supportive, interior, spatial element in making this differentiation. Rifat

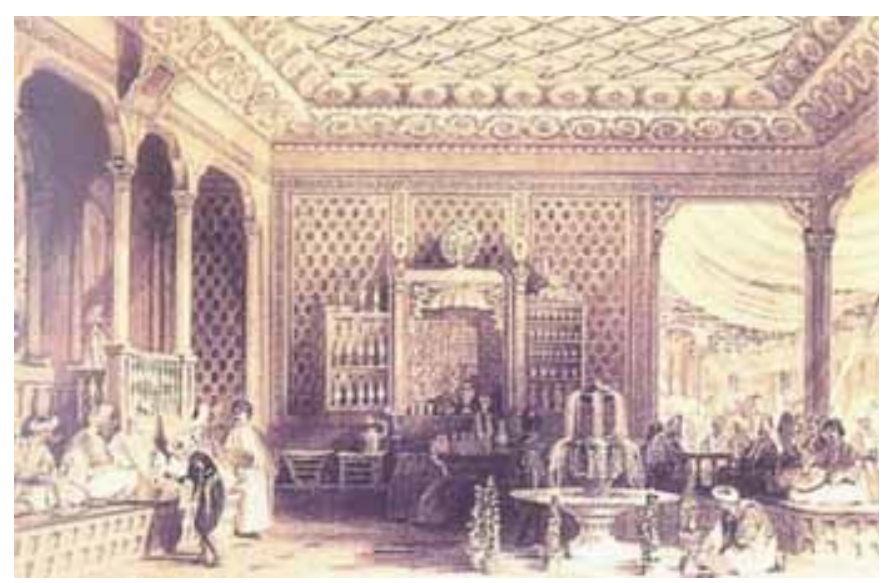

Figure 1: Ottoman coffeehouse in 18th century [13].

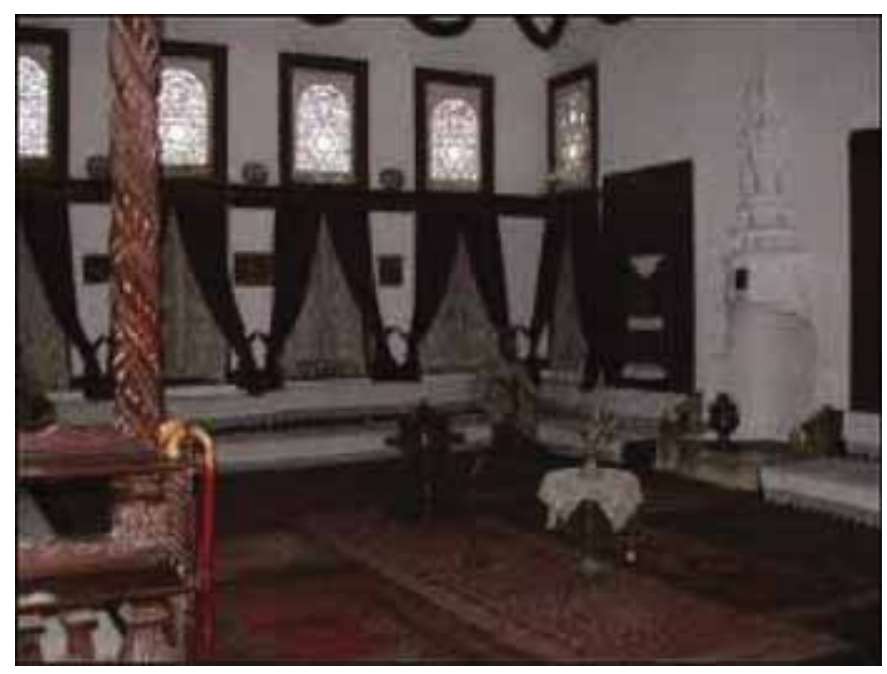

Figure 2: A view from Konak sitting room [13]. 
Osman Bey (Dr Rifat Osman), having visited many coffeehouses in Anatolia, described a top divan as follows:

'There is a top divan for 20 to 25 people across from the corner where the stove is, accessed by two steps on a narrow staircase (resembling mosque maksoorahs, whose surroundings were fenced in), and having a wooden bedstead' [14].

The plan schemes (Fig. 3) were taken from Türk Etnografya (Turkish Ethnography) magazine, published in 1962. The scheme was prepared by Dr Rifat Osman Bey in 1932 and was published in the 87th issue of Belediye Mecmuast (Municipality Periodical). As can be seen, there is a central pool, surrounded by a square. This square is surrounded by wooden bedstead seating units and the stove area. The top divan and garden are frequently used elements.

According to Heise, the coffeehouse owner's finances determined whether or not elements such as pools were present. The wooden bedstead seating unit was a typical accommodation seen in each coffeehouse. A top divan was present in a corner outside the common sitting area. The stove was in another corner, outside the central place. In other words, different functions were placed at the perimeters in a space designed in a centripetal order.

A common feature of coffeehouses was that interaction between interior and external spaces was strong. A permeable interior and exterior space relationship was created with the help of large openings and seating that spread out to the gardens in the exterior space.

In the coffeehouse examples given above (Fig. 4), the authors note that the coffeehouse was occasionally located in the exterior space. Especially in İstanbul, coffeehouses were built in locations with breathtaking panoramic views. Pier Loti coffeehouse is one such example. According to Salah Birsel, the English writer Julia Pardoc (who visited İstanbul in 1835) talked about the view of İstanbul seen from Pier Loti coffeehouse with these words:

'One cannot get enough of Istanbul as seen from the Eyüp hills. The holy city extends towards Sarayburnu with golden crescents of mosque domes shining under the sun and white minarets ascending to the sky. The Bulgurlu hills are seen far away on Asian soil, while crests in the Bosporus Straits are seen towards the northeast' [15].

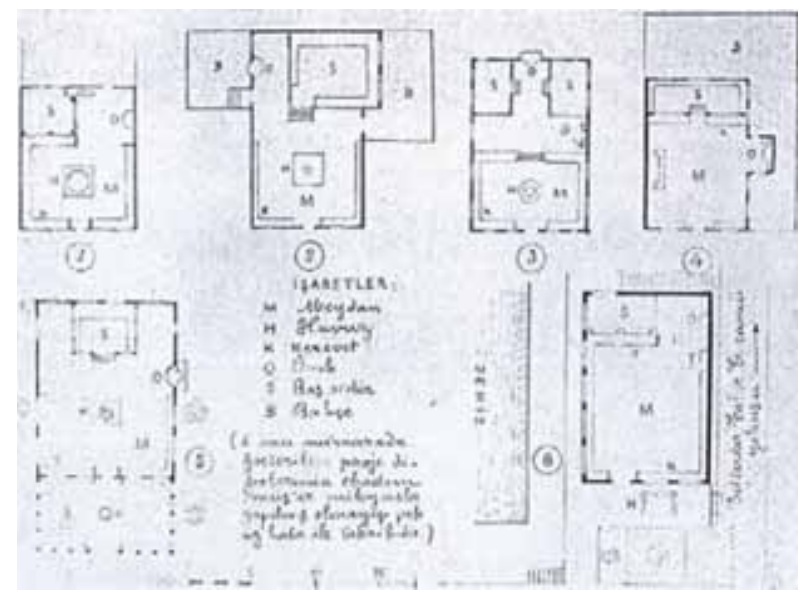

Figure 3: Interior space plan schemes in coffeehouse [14]. 


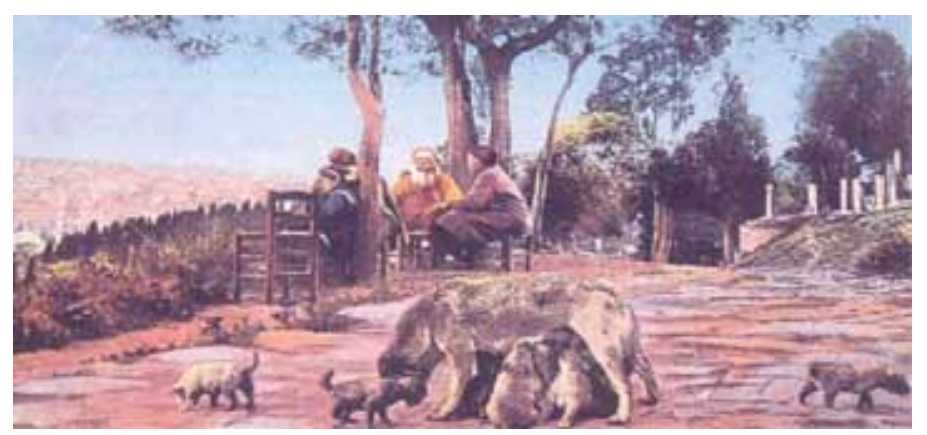

Figure 4: Exterior space view of Ottoman coffeehouses [14].

However, in some coffeehouses the garden was furnished in compliance with seating order. In addition, large openings were designed in the interior space to maximize the view. Heise explains the strong interaction between interior and exterior spaces of coffeehouses as follows:

'In every place where internal and external differentiation was overcome by architecture (lockable window sashes, small openings on the walls, columnar porches, where benches are present, under the roofs surging to the outside, wooden summerhouses with one or two floors facing towards one or more directions), a valid standard developed' [16].

Evaluating the elements in interior space, it is seen that columns are one of the most highlighted decorative elements. These columns, generally found in open areas in interior space, are intensively decorated with ornaments. The coves connecting these columns to each other, and the capitals and bases of columns, are the most elaborately decorated parts of the columns.

Considering other decorative elements of the interior space, it is seen that, initially, city coffeehouses used many highly furnished decorative elements. This ornamentation includes columns, joists, walls, and ceiling, and in shaping many other decorative elements. Heise explained these ornaments as follows: 'There is a showy, ceramic coffee stove and there are papier-mâché ornaments extending towards the ceiling'. Heise stated that divans were also furnished with carvings and that 'interior decoration of some of these elite coffeehouses is more showy than a European can imagine' [16].

In terms of the interior decor of coffeehouses, one of the most important decorative elements is the stove. The stove is located in an open area and may also serve a storage function. The cupboards and shelves surrounding it are the most functional decorative elements in a coffeehouse. The stove, shelves, and cupboards in which coffee pots and cups are stored work together as a single unit. Coffee and coffee services are made in this unit.

Despite some differences between coffeehouses, stoves are mostly decorated with intensive ornaments (Fig. 5). In addition, stoves were positioned to dominate the interior space. On both sides of the stove, there are shelves in which coffee cups and other materials are stored [13]. In many sources, these shelves are termed 'hole'. According to observations by Rifat Osman Bey (recorded in the studies of Süheyl Ünver):

'In old coffeehouses, there is a beautiful stove made of plasterwork with adorned headings. At its right and left, there are shelves placed inside the wall, whose surroundings are embossed with plasterwork decoration. The names of these shelves are holes. Cups, whose previous names were "tas", bowls, and zarfs are placed in order... . There are narrow and high cupboards, 


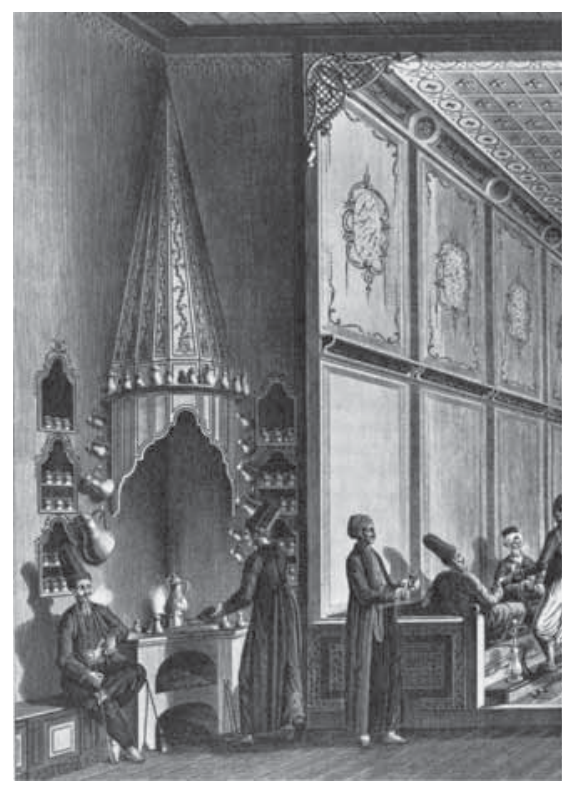

Figure 5: Stove unit [15].

near holes, which are placed inside the wall with wooden doors. At first, chopsticks, and later, flexible hookah pipe tubes were stored inside these cupboards' [14].

In addition, Rifat Osman Bey stated that cups and zarfs of coffeehouse veterans and respected customers were kept on a separate shelf. The stove is the place where only coffee is cooked in the interior space and a decorative element to which many different meanings were attributed. It is also an indicator of the prestige of the coffeehouse's customers.

Divan is another important ornament element. The wooden bedstead sitting unit was the same as that used in an Ottoman guest room's seating arrangement. Chairs were not used in Ottoman times. This type of seating, also referred to as a wooden bedstead, was a pillowed and cushioned place to sit, 20 or $30 \mathrm{~cm}$ higher than the floor. Divans were externally covered with wicker.

Another important decorative element in interior space is the pool. Hattox gives place to Thevenot's writings on the use of water dating back to the 1700s. Thevenot's observations are as follows:

'All the coffeehouses of Damascus are beautiful; they are cool, pacifying and pleasant places with many fountains, rivers running alongside, places shadowed by trees, roses and other flowers' [17].

Water was part of coffeehouses because of its pacifying effect and coolness. Pools were used in coffeehouses with both functional and aesthetic goals. These intensively decorated pools were an effective decorative element in the interior space.

As mentioned above, generalizations about interior places differ in some coffeehouse examples. The seating order in storyteller (meddah) coffeehouses was designed differently from other coffeehouses for patrons to watch the performance of the storyteller. These coffeehouses have a kind of theater seating arrangement, with their stages and audiences. The same seating arrangement is seen in coffeehouses where Karagöz shadow puppet plays are performed.

During the month of Ramadan, many coffeehouses were decorated in accordance with activities. It is known that there were coffeehouses famous only for their decorations. 'Some ornaments were 
talked about by the public, and this discussion was a kind of advertisement for the coffeehouse in question' [14]. These ornaments were generally made of graphone and other glossy papers. These were hung down from the ceiling and used for decorations surrounding the stage [15].

Other than the great and showy city coffeehouses, the next most frequently encountered coffeehouse type was the local coffeehouse. These coffeehouses, found in almost every neighborhood, were less showy places in comparison to big city coffeehouses. Evaluating local coffeehouses in terms of style, there were generally some concerns about basic practical decisions taken to carry out functions rather than concerns of having a style.

Interaction between interior and exterior spaces in these coffeehouses was very strong. As in large city coffeehouses, a strong visual relationship was created between interior and exterior spaces by means of large openings. Mostly in summer, the seating was entirely located outside, with wicker stools that are still used today. Wooden bedstead seating units were also used both in interior and exterior spaces in these coffeehouses.

There have also been changes over time in the appearance of coffeehouses, in line with the changing social structures. Renovation efforts made after the foundation of the Republic, immediately following the Ottoman Era, formed the basis for these changes. With the Westernization movement, attempts were made to make coffeehouses look more like their European counterparts. Turkish coffeehouses of that time display particularly strong influences from those of Vienna.

However, the nationalistic movements that emerged in Europe during the Second World War period also started to have an effect in Turkey. During this period (the early 1940s), national values gained prominence in architectural design. A synthesis was forming which was national and yet could meet the requirements of the era. This was independent of any pursuit of an 'international' style. International style is an architectural movement that started in 1920s and aimed to develop a universal architectural

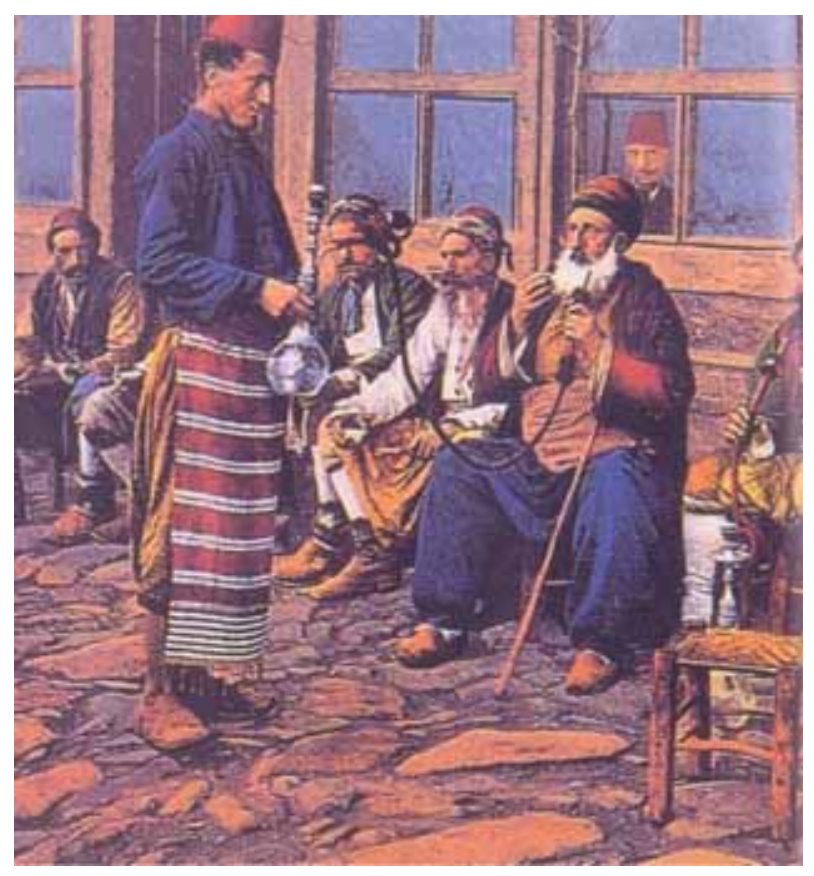

Figure 6: Views from local coffeehouses [13, 14]. 


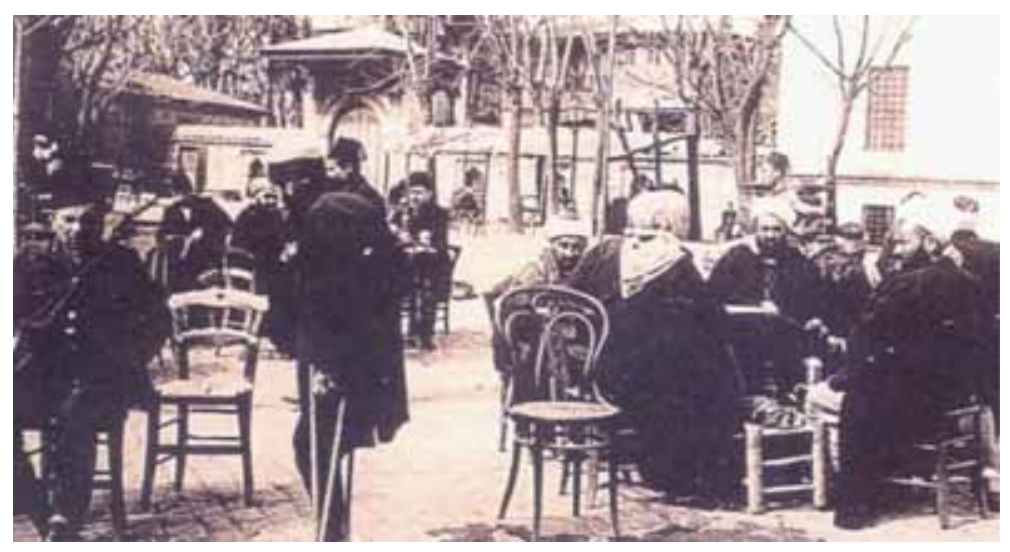

Figure 7: Coffeehouse exterior space at the beginning 20th century [13].

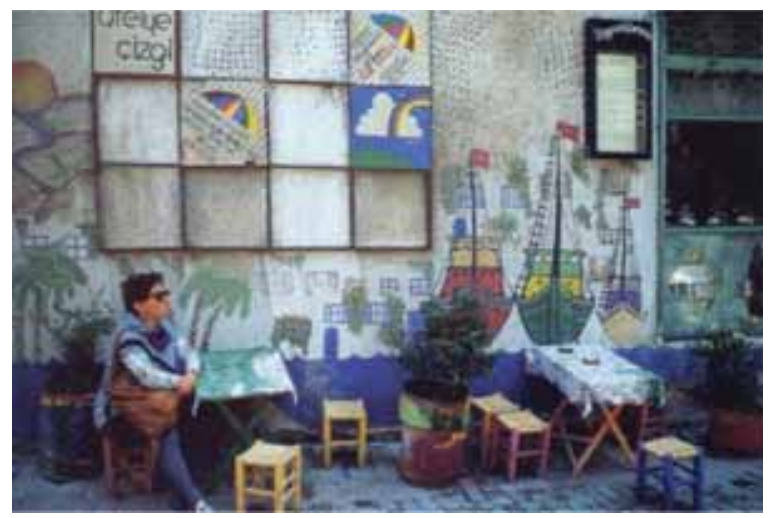

Figure 8: Current examples of coffeehouse exterior seating elements [18].

expression. Thus, coffeehouses reformed with influences based on their past configurations. However, by the 1950 s, various socialization spaces other than coffeehouses started to open, including patisseries, cafes, and restaurants. These new types of spaces affected the usage of the coffeehouses.

With all of these complex social changes, coffeehouses became areas of socialization that were behind the times, failing to keep up with Turkish society in general. Coffeehouses cannot adapt to new consumption patterns and the fast pace of urban life. Traditionally, people would spend their time in coffeehouses for chatting and in getting to know each other. Especially with the effect of mass consumption, shopping malls have become the favorite setting in which people spend their leisure time. This is a time not for socializing but actually for consumption. Today, coffeehouses are still not able to keep up with these new forms of socialization. However, a limited number of coffeehouses, used for touristic purposes, have a comparatively broader customer base than the others.

\subsection{Typical elements in Turkish coffeehouses}

Examining samples dating back to the 1500s and surviving until today, it is seen that the interior spaces of coffeehouses are still used, despite being affected by social changes. It is also observed that 


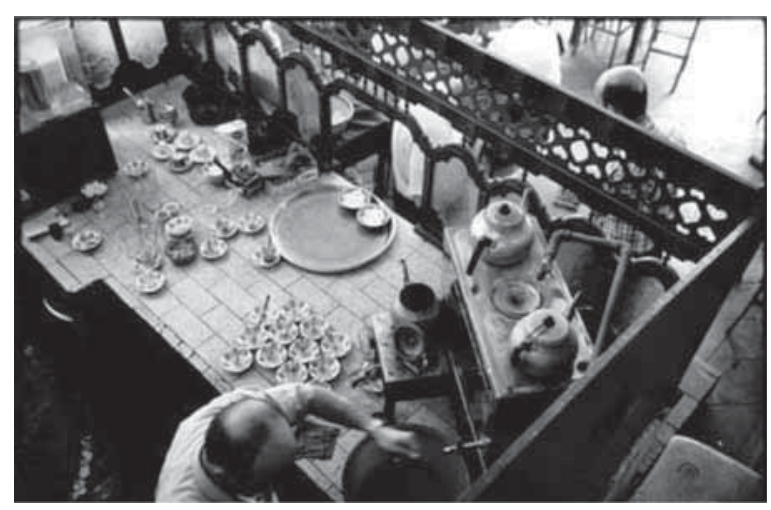

Figure 9: A coffeehouse brewing area [18].
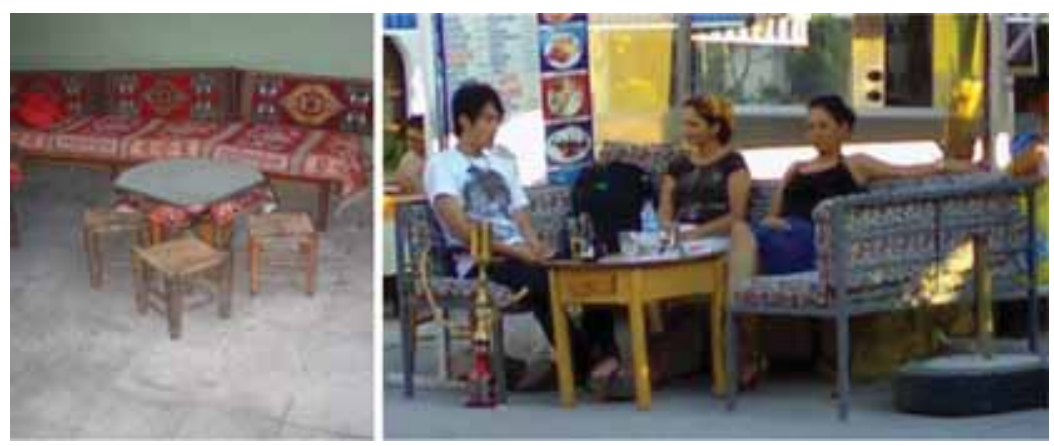

Figure 10: Exterior seating units, Asma Alti coffeehouse in Kizilay, Ankara (Ayalp Archive, 2007).

these socialization places, used for such a long period of time, created their own identities. Looking at existing examples in the light of this historical information, although functionality may differ, repeated characteristics can be observed in the configuration of the interior space of the coffeehouses. These typical characteristics are:

- A holistic interior space set up in a space configuration

- Permeable interaction of interior and exterior space

- Typical decorational elements;

— Stove unit

— Wooden bedstead seating units

— Use of wicker stools

These typical elements are vital in users' experience in a way that these typical elements reflect an image in the users' cognition. The cognitive process is formed by traditional types that are shaped through history. According to Norberg-Schulz, people perceive the world through types and these types structured our cognitive schemes. From this point of view, Auburn and Barnes summarize the approach as follows: 
'The person's representation or stock of knowledge of the world, first, is social in that its typified content arises in and through the community and its history. Furthermore, typification is underpinned by language, or more precisely the "vernacular of the collectivity" [19].

Sustainability of setting conveys through typical elements. The traditional Turkish coffeehouse can be regarded as a form of cultural heritage since it has a typical space understanding. These typical elements are fundamental in representing the cultural place identity. In further sections, a model for the sustainability of cultural heritage will be introduced in the context of coffeehouse.

\section{DESIGN MODEL FOR SUSTAINABILITY OF CULTURAL SETTING}

Based on the discussion above, it is apparent that Turkish coffeehouses are a part of the country's cultural heritage. However, previous studies indicate that this cultural value has not been sufficiently transferred to the present day. Due to problems arising from their inability to adequately adapt to modern living conditions, the use of traditional coffeehouses by city dwellers has been limited. In short, coffeehouses cannot adapt to new consumption patterns and the fast pace of urban life. Thus, this space which used to encompass the concept of place for earlier generations lost its particular characteristics.

The formal and fundamental effort required to address this problem depends on the designer being able to achieve a design that incorporates cultural values at the image construction phase. The image is considered as the appearance of the coffeehouse that has a unique identity. These unique identities of the typical features are the reflection of the cultural identity developed through the repetition. Through the history, these repeated features turn into typical elements that form the specification of the identified image. The elements that constitute the typical characteristics of the traditional Turkish coffeehouse, as established above, need to be included at the base level of the design. That way, a unique type of design at a local level could be achieved.

When, the typical image of the coffeehouses is analyzed within the dimension of cultural identity, the holistic interior space understanding reflects the needs of some social interactions. Moreover, typical image as the permeable interior and the exterior space serves for the strong interaction with the street. As the coffeehouse is a social gathering space for the Turkish culture, these identified features reflect the cultural needs. Besides, the typical functional and decorational elements, such as stove, wicker stools, wooden beds seat unit, reflects the local, traditional ways of cooking and seating. Briefly, all these elements display a unique image that reflects the socio-cultural living habits.

In addition to certain conditions that need to be taken into consideration in the formation of the coffeehouse image, important points that influence the acceptance of the designer in general must also be considered. One of the most important points is that the design should adequately meet user requirements, as customer satisfaction is a major factor in the repeated use of the space. The space needs to have certain standards applied in order to ensure its correct operation. It is important for the space to meet the user needs in an ergonomic sense.

Another element in creating a new coffeehouse image is to realize that it must take on contemporary conditions and forms. The image should not simply replicate the past, and not simply mimic the existing characteristics in a modern design. Instead of exactly applying certain forms used in the past, it is important to convey these by way of an abstract and contemporary presentation. In other words, the designed interior space needs to be an interpretation, which conveys the unique values of the past but reconfigures them in the light of present.

The design of coffeehouse interior space must be adapted to modern utility requirements. The space must be configured for a contemporary presentation. Modern eating and drinking patterns must be taken into account in setting up the space to increase its utility. 


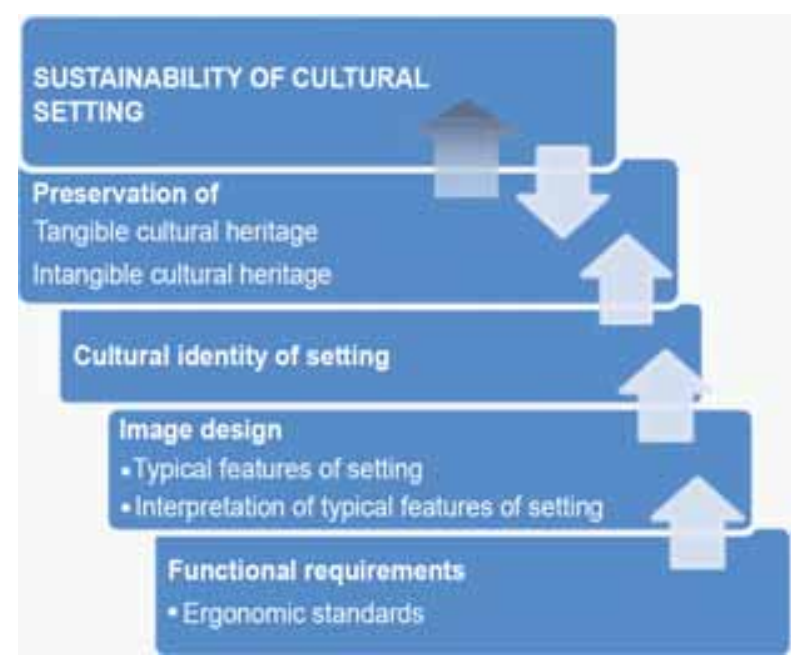

Figure 11: Sustainability of cultural setting.

The above model is the phased expression of the coffeehouse image formation, providing a systematic presentation of the proposed recommendations. It emphasizes the need to achieve culturally unique semantic content through the characteristics typical of the coffeehouse's interior. It is suggested that, in this way, a typical cultural setting can be sustained. Moreover, sustaining the coffeehouse setting forms the basis to safeguard the intangible parts of this cultural heritage, especially the way in which people socialize.

Creating a renovated image for various forms of cultural heritage has played a crucial role in the regeneration of declining urban, industrial, and rural areas through tourism and conservation programs [20]. According to Uzzell, 'interpretation needs to be planned and designed with that outcome in mind'. In an article named 'Interpreting our heritage', Uzzell also states that 'interpretation in places and group identities does not have to be divisive', and also claims that 'both the motivations to visit and the kind of benefits derived from visiting heritage sites can be seen in terms of individuals seeking to identify with a place and, as a consequence, deriving from that identification a positive self-image'.

\section{CONCLUSIONS}

Sustainability of a cultural value can only be conveyed through sustaining the environment that contains the specific value. In this case, the interior space is a cultural heritage and contains the specific intangible cultural heritage. Both the coffeehouse interior space and the socializing ritual of preparing and drinking manners are part of cultural heritage. This reflects the specific living habits of a culture. In other words, it reflects the identity of the culture. As is known, the culture is a way of being, relating, behaving, believing, and acting which people live out in their lives and which is in a constant process of change and exchange with other cultures [21].

It is obvious that the interior space is a constant factor that affects the formation of culture identity. There is a two-way interaction between the space and the user. Thus, the user is the mediator in shaping culture within this constant process of change and exchange with other cultures. In this process, the proposed model aims to sustain the image of a setting without losing its culturally unique semantic content. As, UNESCO emphasized 'to be kept alive, intangible cultural heritage must be relevant to its community, continuously re-created and transmitted from one generation to another' [22]. 


\section{REFERENCES}

[1] Aikawa, N., An Historical Overview of the Preparation of the UNESCO International Convention for the Safeguarding of the Intangible Cultural Heritage. Museum International Vol. 56, Blackwell Publishing: Oxford, pp. 137-149, 2004.

[2] Burra Charter., The Australian Charter for the Conservation of Places of Cultural Significance, 1979.

[3] Vecco, M., A definition of cultural heritage: from the tangible to intangible. Journal of Cultural Heritage 11, pp. 321-324, 2010. doi: http://dx.doi.org/10.1016/j.culher.2010.01.006

[4] Altman, I. \& Low, S (eds)., Place attachment: a conceptual inquiry. Human Behavior and Environment, Vol. 12, Plenum: New York, 1992. doi: http://dx.doi.org/10.1007/978-1-4684-8753-4

[5] Kenz, I., Attachment and identity as related to a place and its perceived climate. Journal of Environmental Psychology, 25(2) pp. 207-218, 2005. doi: http://dx.doi.org/10.1016/j.jenvp. 2005.03.003

[6] Hay, R., Sense of place in developmental context. Journal of Environmental Psychology, 18, pp. 5-29, 1998. doi: http://dx.doi.org/10.1006/jevp.1997.0060

[7] Law, A. \& Altman, C., Culture and Environment. Cambridge University Press: Cambridge 1989.

[8] Twigger-Ross, C.L. \& Uzzell, D.L., Place and identity processes. Journal of Environmental Psychology, 16, pp. 205-220, 1996. doi: http://dx.doi.org/10.1006/jevp.1996.0017

[9] Van Eyk, A., Labyrinthine clarity. World Architecture Three, pp. 120-129, 1996.

[10] Dorren, M., Space-time and politics of location. Architectural Design Profile, 132, pp. 34-39, 1998.

[11] Tajfel, H., Social Identity and Inter-group Relations. Cambridge University Press: Cambridge, 1982.

[12] Proshansky, H.M., Fabian, A.K., \& Kaminoff, R., Place identity: physical world socialization of the self. Journal of Environmental Psychology, 3, pp. 57-83, 1983. doi: http://dx.doi. org/10.1016/S0272-4944(83)80021-8

[13] Evren, B., Eski İstanbul Kahvehaneleri. Milliyet Yayınları: İstanbul, 1996.

[14] Ünver, S., Türkiye'de Kahve ve Kahvehaneler. Türk Etnografya Dergisi. Türk Tarih Kurumu: Ankara, 1963.

[15] Birsel, S., Kahvehaneler Kitabı. Koza Yayınları İstanbul, 1975.

[16] Heise, U., Kahve ve Kahvehaneler. Dost: Ankara, 2001.

[17] Hattox, R.S., (Çeviren Nurettin Elhüseyni) Kahve ve Kahvehaneler. Tarih Vakfı Yurt Yayınları: İstanbul, 1998.

[18] Eczacıbasi, S., Kahvehaneler. Eczacıbaşı: İstanbul, 2006. Selehattih G, 1989, Beyoğlu 1930. Çağdaş Yayıncılık: İstanbul.

[19] Norberg-Schulz, C., Genius Loci, Towards a Phenomenology of Architecture. Rizzoli Publ: New York, 1991.

[20] Uzell, L., Interpreting our heritage: a theoretical interpretation. In: D.L Uzell \& R. Ballantyne, eds, Contemporary Issues in Heritage and Environmental Interpretation: Problems and Prospect. The Stationery Office: London, pp. 11-25, 1998.

[21] United Nations Decade of Education for Sustainable Development 2005-2014 (Draft International Implementation Scheme, October 2004), p. 4.

[22] "Safeguarding without freezing" UNESCO Intangible Heritage 2003 Conventions available at http:/www.unesco.org/culture/ich/ 